\title{
Bairektorevich A.
}

\section{Eastern Europe - The World's Last Underachiever*}

\begin{abstract}
Review. This study concerns the development of the Eastern Europe and its current geopolitical status. The political study is undertaken of the example of the after WWII development of this region. Cultural, social, economical and political aspects of the Eastern Europe and its contemporary development are taken into consideration. An important part of the study concerns current Ukrainian crisis. The evolution of the role of the NATO in Europe is described and taken by the author as one of the major causes of the current crisis in Ukraine. Author depicts current development of the eastern Europe as Ukrainization or Pakistanization. Author argues that Ukraine and Europe became a hostage of the US's aggressive politic. Author also points out that by annexing Crimea Moscow showed to US and Europe that Ukraine is an emotional place for Russia - tied to it by a bond of historio-civilizational attachment - something that makes and sustains Russia both Christian and European
\end{abstract}

Keywords: politics, crisis, Politics, Eastern Europe, Europe, United States of America, Ukraine, NATO, Russia, geopolitics.

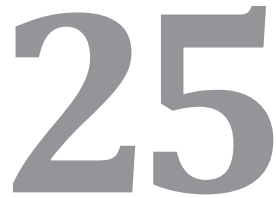

years ago, the Russian historical empire melted down. Although often underreported, this also marked the end of alternative society in Europe. Collapse of the II world, made the 3rd way (of Yugoslavia and further, beyond Europe - globally, of the Nonaligned Movement) obsolete.

That was a moment when the end of history ${ }^{[3]}$ rested upon all of us, the day when the world became flat. The EU entered East, but only as a "stalking horse" of NATO. No surprise that Eastern Europe has soon after abandoned its identity quest, and capitulated. Its final civilizational defeat came along: the Eastern Europe's peoples, primarily Slavs, have silently handed over their most important debates - that of Slavism, anti-fascism and of own identity - solely to the recuperating Russophone Europe.

\section{Terrified} and rarified underachievers

Is today's Eastern Europe a classic case of indirect rule? Is that a deep imperial periphery of nominally independent native

All displayed maps per the author's idea made by Anneliese Gattringer 


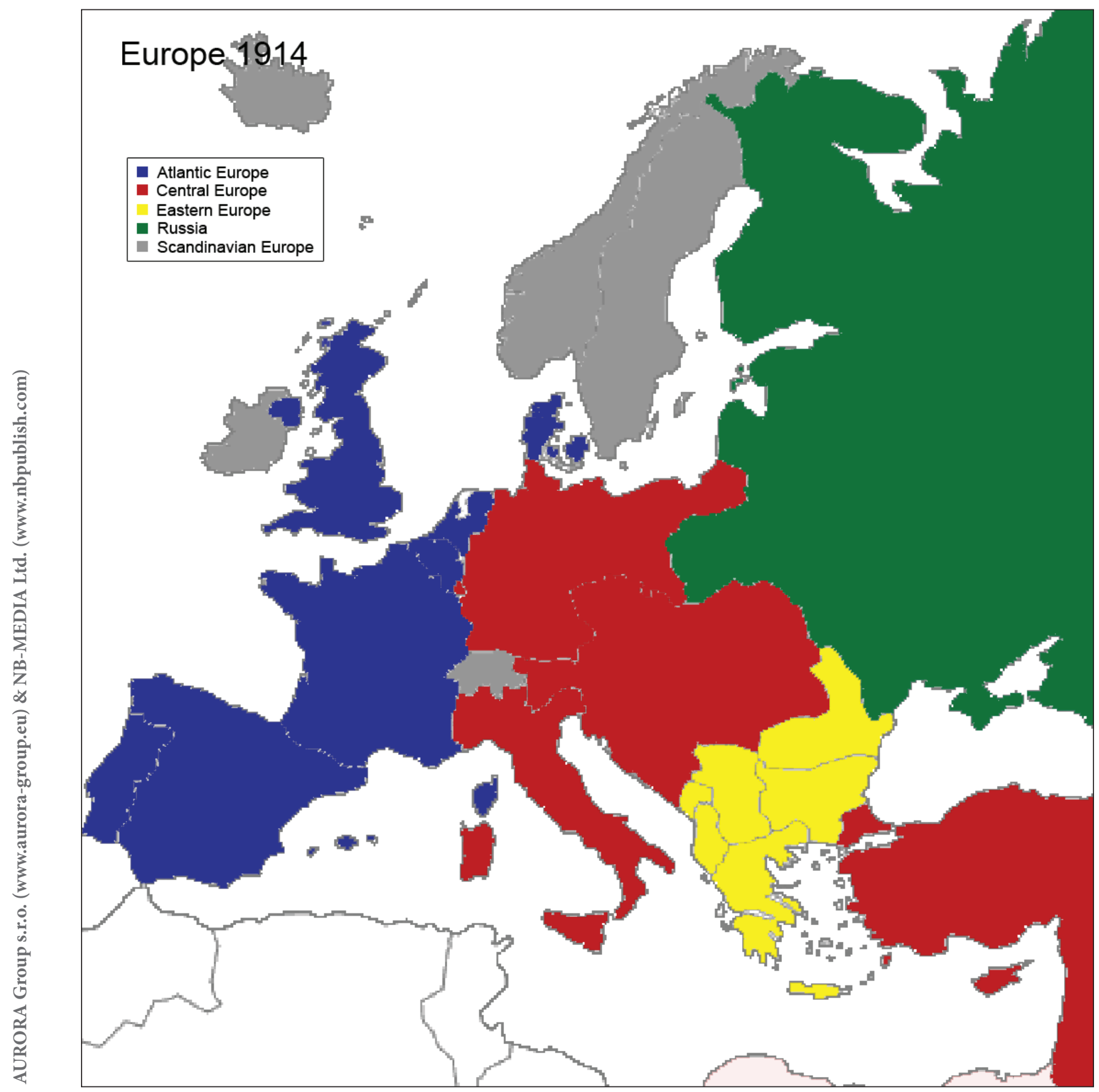

rulers, while in reality the true power holder resides outside, although is domestically supported by a dense web of NGOs, multinational corporations and locally handpicked "elites"?

$* * *$

Everything in between Central Europe and Russia is Eastern Europe, rather a historic novelty on the political map of Europe (see four maps above). Very formation of the Atlantic Europe's present shape dates back to $14^{\text {th }}-15^{\text {th }}$ century, of Central Europe to the mid-late $19^{\text {th }}$ century, while a contemporary Eastern Europe only started emerging between the end of WWI and the collapse of the Soviet Union - meaning, less than 100 years in best cases, slightly over two decades in the most cases. No wonder 


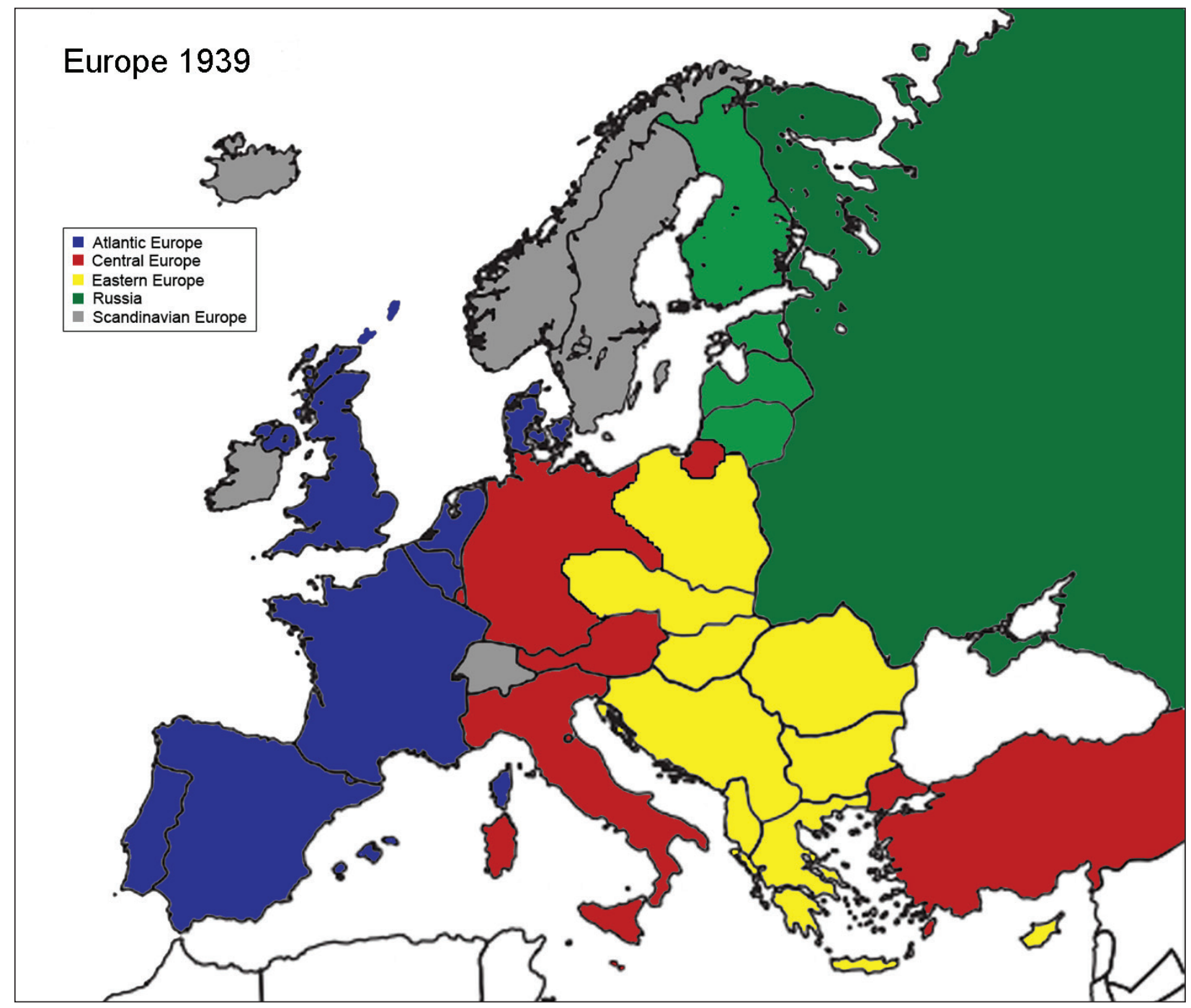

that the dominant political culture of the Eastern Europeans resonates residual fears and reflects deeply insecure small nations. Captive and restive, they are short in territorial depth, in demographic projection, in natural resources and in a direct access to open (warm) seas. After all, these are short in historio-cultural verticals, and in the bigger picture-driven long-term policies. They are exercising the nationhood and sovereignty from quite a recently, thus, too often uncertain over the side and page of history. Therefore, they are often dismissive, hectic and suspectful, nearly neuralgic and xenophobic, with frequent overtones.

The creation of a nation-state (on linguistic grounds) in the Atlantic, Scandina- vian and Central Europe was relatively a success-story. However, in Eastern Europe it repeatedly suffered setbacks, culminating in the Balkans, Caucasus and the Middle East, but also remains evident in the central or Baltic part of Eastern Europe.

Above statement might come as a shock for many. Why? For the last 25 years, our reporting on Eastern Europe was rather a matter of faith than a reflection of the empirical reality. This "rhetoric" was dominated by fragmented intellectual trends that are more cultural (e.g. poetry, paintings, film, etc.) than coherently economic and geo-political in focus as they should be. How one defines a challenge largely determines the response - effec- 


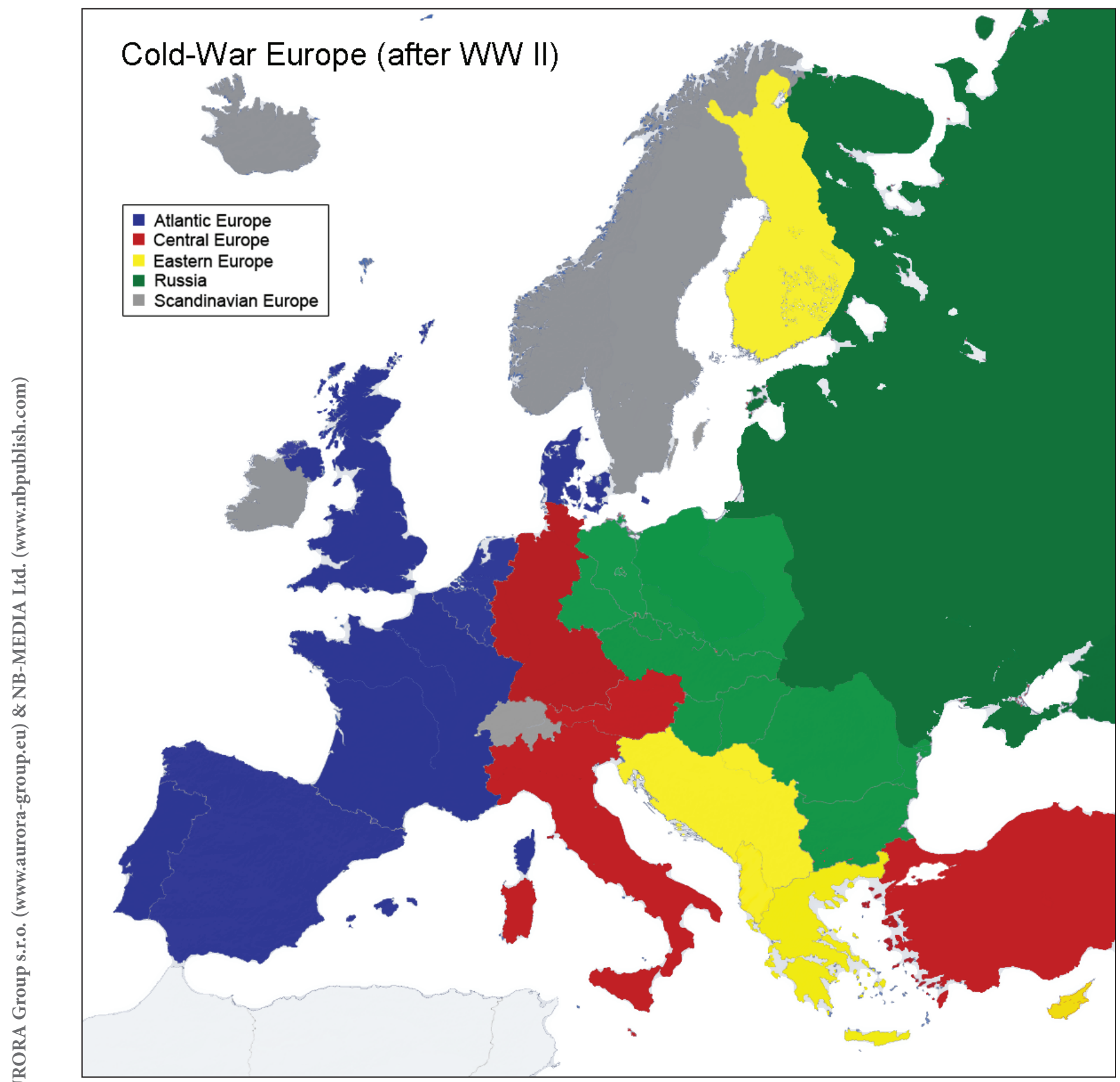

tively points out Brzezinski ${ }^{[2]}$. Hence, the arts will always elaborate on emotions, science will search for and examine the facts.

If the front of Atlantic-Central Europe lately suffered (an economic) problem which has been diagnosed as a distributional and compositional, than who and when is holistically and scientifically to examine the Eastern-Rusophone Europe and its burning geo-economic (distributional, compositional), socio-political/ideological (space-time in history) and geopolitical (logical and areal) problem? Where is a serious research on that?

If the equality of outcome (income) was a communist egalitarian dogma, is the belief in equality of opportunity a tangible reality offered to Eastern Europe or just a deceiving utopia sold to the conquered, plundered, ridiculed and cannibalized countries in transition? 


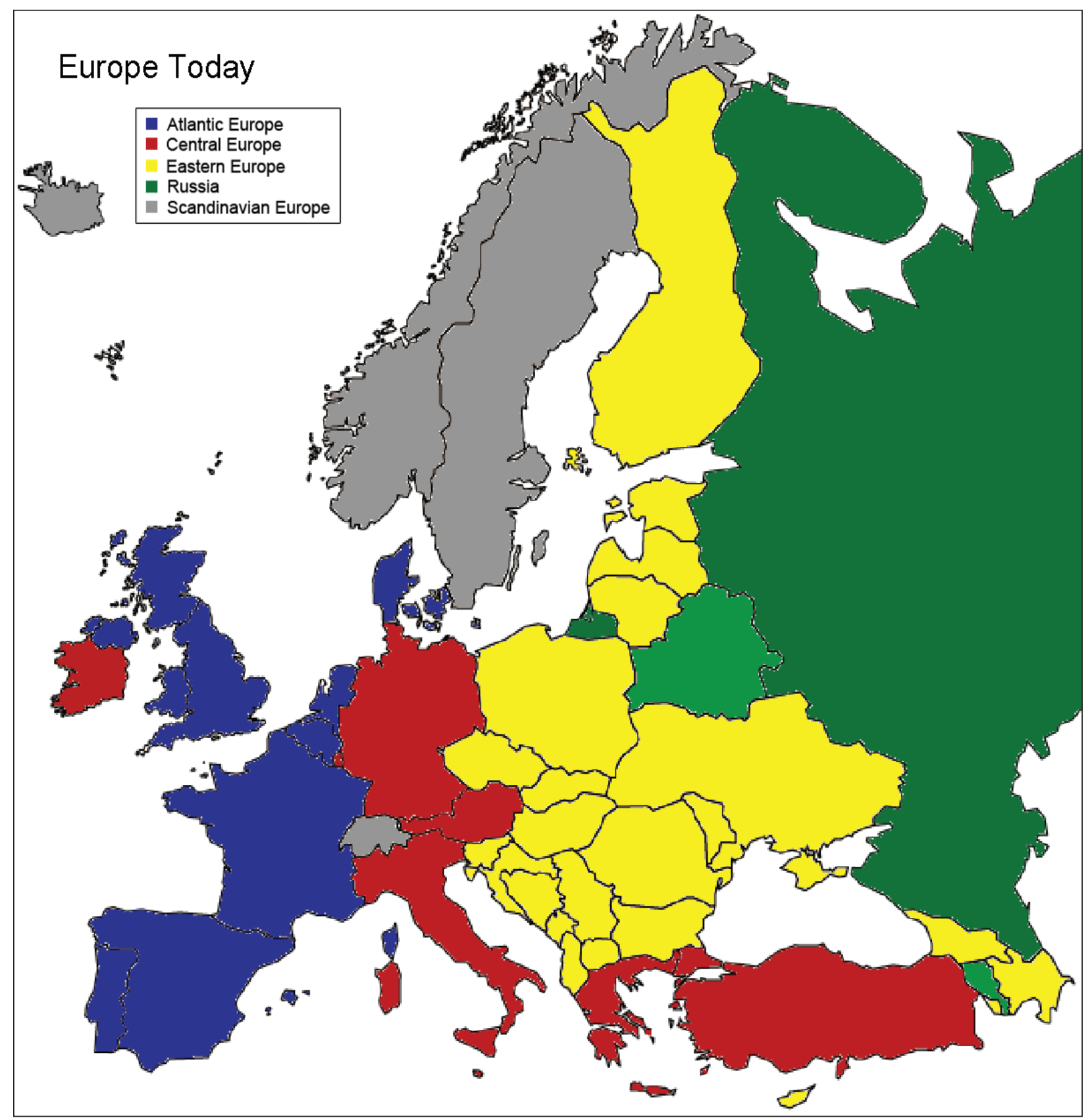

What is the current standing of Eastern Europe - state of its economy, the health of its society and the efficiency of its governance?

By contrasting and comparing available HDI data (UN DP's Human Development Index) and all relevant WB, OECD, UNCTAD, ILO and WHO socio-economic and health indexes including the demographic trends of last two decades, we can easily spot a considerable green, economic and socio-human growth in
Asia, in Latin America and moderate growth elsewhere. The single trend of negative growth (incl. the suicide and functional illiteracy figures) comparable by its duration and severity to this of Eastern Europe, is situated only in the sub-Saharan Africa (precisely the CHAD-lake region and partially between Grand lakes and Horn of Africa). Further on, recent generational accounting figures illuminate a highly disturbing future prospect for the youth of Eastern Europe. 
Neither their economic performance nor birth rates would sustain the financial burden left for the future by the present, irresponsible and defeatist, generation.

Ergo, euphemisms such as countries in transition or new Europe cannot hide a disconsolate fact that Eastern Europe has been treated for 25 years as defeated belligerent, as spoils of war which the West won in its war against communist Russia. $A$ sharp drop in LE (life expectancy) in Russia, from age 72 to 59, is something faced only by nations at war. The evidence that Russia has suffered such a steep decline, unreversed ever since the collapse of the Soviet Union, is unprecedented in a peace-time history of any industrialized nation. Although not so alarming like in the post-SU Russia, the rest of post-Soviet republics and Eastern Europe closely follow the same LE pattern - not to mention devastating birth rates, brain drain and other demographic data. E.g. the projected LE of the today's born Berliner is around 100 years, while of Muscovite is only 67 years. Simply, the East is unable to (re-) produce its own life. Or, once it is conceived, to keep (the best of) that life at home. Some would argue that it again is the war for a lebensraum, but this time of the self-imposed Endlösung (final solution).

It concludes that (self-)fragmented, deindustrialized, rapidly aged rarified and depopulated, (and de-Slavicized) Eastern Europe is probably the least influential region of the world - one of the very few underachievers. Obediently submissive and therefore, rigid in dynamic environment of the promising 21st century, Eastern Europeans are among last remaining passive downloaders and slow-receivers on the otherwise blossoming stage of the world's creativity, politics and economy. With some exceptions of Visegrád countries (such as Poland or Czech Republic, and lately Hungary) sporadically opposing a constant bandwagoning (but even that only in the domain of narrow $E U$ fiscal or economic matters), Eastern Europe of today is unable to conceive and effectively promulgate a self-emancipating, balanced and multivector foreign policy. Fergusson goes as far as to claim for Eastern Europeans that: "they looked at Brussels (of NATO) the way former British colonies obeyed everything said and done in London.".

East does not exercise its political sovereignty (gone with the EU), its military sovereignty (gone with the NATO), its economic and monetary sovereignty (gone with the massive domestic de-industrialization "preached" by the IMF, EBRD, EIB and eventually ECB), ("The entry criteria for Eastern European states was particularly costly: the so-called small and open economies, deindustrialized and over-indebted didn't have any chance to be equal partners. For most of them, FDI (Foreign Direct Investment) is the only economic solution, which turned them into colonies..." - admitted even the Nobel laureate, economist Stiglitz in his The Price of Inequality. Moreover, the overly strong and rigid exchange rate of the domestic currencies in Eastern Europe is good only for foreign landers. It awards importers while disadvantages domestic manufacturing base and home exporters. This outdated anti-growth and anti-green economic policy has been universally abandoned long ago, even by the $L D C$ (the UN-listed Least developed countries). No wonder that the GDP in the most of Eastern European states is well below its pre-1990s levels, and their ecological footprint index is of an alarming trend.) and its financial sovereignty (gone by full penetration of German, Austrian and Swedish banks). According to findings of the Budapest Institute of Economics (Corvinus University), for the past two decades, the volume of Austrian banking sector has increased $370 \%$. How is this spectacular percentage achievable for the country of a flat domestic economic and negative demographic growth? This covert occupation of south-eastern Europe by the foreign financial 
sector did not create new jobs or re-create any industrial base there. As the Budapest Institute concluded aftermath, it was only meant to dryout the remaining liquid assets (and private savings) from the rapidly pauperized, defeated belligerent. In 1914, Austria controlled banks as well; in Croatia, Bosnia, western Romania, northern Serbia, Hungary, southern Poland and western Ukraine. However, at that time, it also had a strict governing obligation as all of them were a part of the Monarchy. By having recognized the formal sovereignty to each of these entities, Austria today (like Sweden towards the three Baltic States in the northeast flank of Europe, and Germany in the central sector of Eastern Europe) has no governing obligations whatsoever. It can easily externally socialize (externalize) all its costs including banking risks, and individualize all profits (internalize), yielding it only for itself. Hence, the EU accession criteria, combined with a nominal independence of Eastern European entities (pacified by the pre-paid media and guided by the post-paid "elites"), means that the economic and other assets are syphoned out, but the countries have to take a burden of the state maintenance solely on themselves. "Creating the market economy attractive for FDI (foreign direct investments) in our case meant a de-industrialization, pauperisation, which eventually led to defunding of most of the state social activities. When someone dare say "our education, housing and health sectors are knocked down due to this", they are quickly denounced as socio-romantics and accused for the social conservatism..." says Head of the Croatia's Economic Institute prof. Slavko Kulic, and concludes: "...suffering of ever larger segments of societies means nothing to the architects of misery, to those Talibans of neoliberalism." Recently released edition of the Oxfam study on the wealth distribution worldwide, unfortunately, confirms this bleak picture.

Those national currencies still existing in Eastern Europe lost - for already long ago - the vital substance: their anthropological and economic function.

Most of the Eastern European states do not control a single commercial bank on their territory. Current labor relations in the most of Eastern Europe (Rusophone Europe, too) resembles pictures of the $18^{\text {th }}$ rather than of the 21st century's conditions, especially in the private sector of employment. It is all with a weak or even totally absent trade unionism, dismal labor standards, as well as the poor protection of other essential social, environmental and health rights. "We have stringent labor conditions to the unbearable maximum, so that the few self-styled "top managers" can play golf more frequently and for a longer time... How can you possibly build any social cohesion when disproportionately many suffer for the dubious benefit of the asocial, predatory few..." - confessed to me the Ambassador of one of the largest Eastern European countries who served as a mayor of his country's capital, before his ambassadorship in Vienna.

East does not control its own narrative or (interpretation of) history: Due to the massive penetration of Central Europe, East grossly relativized, trivialized and silenced its own past and present anti-fascism. Additionally, this region does not effectively control its media space. Media there (of toooften dubious orientation and ownership) is discouraging, disorienting and silencing any sense of national pride, influence over destiny direction and to it related calls for self-(re)assessment.

East is sharply aged and depopulated the worst of its kind ever - which in return will make any future prospect of a full and decisive generational interval simply impossible. Some ten years ago, at the special OSCE forum for demographics, I warned: “... lasting political, social and economic changes including very important technological breakthroughs - throughout our history primarily occurred at generational inter- 
vals. This was an engine of our evolution... Presently, with demographically collapsing East European societies (natality rates, generational and brain drain), the young cohort will never constitute more than a tiny minority - in the sea of aged, backward-looking, psychologically defeatistic and biologically incapable, conservative status quo keepers. Hence, neither the generational change that brings fresh socio-political ideas, nor technological breakthrough -which usually comes along - will successfully ever take place in future of such demographies." (For a detailed demographic outlook and tentative recommendations/conclusions, see: Bajrektarevic, A. (2005), Our Common Futures: EURO-MED Human Capital beyond 2020, Crans Montana Forum, Monaco, 2005, as well as Bajrektarevic, A. (2005), Green/Policy Paper Submitted to the closing plenary of the Ministerial (Chairmanship summarizing the recommendations and conclusions of the OSCE Ministerial Summit Prague 2005), OSCE Documents EEA 2005.). Honduras-ization of Eastern Europe is full and complete. Eastern Europe is Hondurized - this term refers to an operationalization of Monroe Doctrine in Central America, by which Washington allows its strategic neighborhood to choose their own domestic political and economic systems to an acceptable degree, while the US maintains its final (hemispheric) say over their external orientation. The so-called Brezhnev doctrine (of irreversibility of communist gains) postulated the Soviet (Suslov-Stalin) equivalent to Honduras-ization - Finlandization. If the post-WWII Soviet occupation of Eastern Europe was overt and brutal, this one is tacit but subversive and deeply corrosive. Eastern Europe, the (under-)world of dramatic aging which, is additionally demographically knocked down by the massive generational and brain drain. Passed the dismantling of the communist order, these emerging economies, countries in transition of the new Europe contain reactionary forces (often glorifying the wrong side of history), predatory "elites" and masses of disillusioned (in a life without respect and dignity, humiliated and ridiculed in the triviality of their lasting decline). Even if the new jobs are created or old kept, they are in fact smoke screens: Mostly a (foreignloans financed) state-sponsored poverty programs where armies of the underemployed and misemployed cry out miserable wages in dead-end jobs. Former Slovakian cabinet minister laments in private: "Our "liberated East" lives on foreign loans, or in the best case as the industrial suburbia of West Europe, having these few "generously" franchised factories like Renault, VW or Hugo Boss. Actually, these are just automotive assembly lines and tailor shops - something formally done only in the III World countries. Apart from the Russian Energia-Soyuz (space-program related) delivery system, what else do we have domestically created anywhere from Bratislava to Pacific? Is there any indigenous high-end technical product of past decades known? ... Our EU accession deals are worse than all Capitulation agreements combined that the Ottomans and Imperial China have ever signed in their history."

\section{East between Ukrainization and Pakistanization}

It is worth reminding that the NATO remains to be an instrument of the US physical, military presence in Europe. Or, as Lord Ismay defined it in 1949: "to keep the Russians out, the Americans in, and the Germans down". The fact that the US remained in Western Germany, and that the Soviet Army pulled out from Eastern Germany did not mean "democratization" or "transition". It represented a direct military defeat of the Gorbachev Russia in the duel over the core sectors of Central and Eastern Europe. As direct spoils of war, DDR disappeared from the political map of Europe being absorbed by Western Germany, while the American Army still resides in unified Germany. Gor- 
bachev's capitulation helped Germans to further gain confidence: Once territorially extended (or to euphemistically say; unified), Western Germany transposed that new size and its centrality into the advanced version of Machtpolitik - drang nach export-based über-economy. No wonder that the überMutti's cabinet is gradually maneuvering the country out of the NATO-enforced Westbindung (an alliance, it does not see any more as its strategic necessity) towards an old, solely/ unilaterally determined Ostpolitik of Wandel durch Kopf-Handel (change via altered mindset). Chancellor Markel's ambassador Michael Schäfer is even more forthcoming on this eventual post-Western Made in Deutschland foreign policy. In the interview for the leading Chinese press he concludes: "I do not think there is such a thing as the West anymore." /Kundnani, H. (2015), Leaving the West Behind - Germany Looks East, Foreign Affairs Magazine 94(1) 2015/. In fact, more than half of the US 75 major overseas military bases are situated in Europe. Up to this day, Germany hosts 25 of them.

Admittedly, by the early 1990s, the "security hole'- Eastern Europe, has been approached in multifold fashion: Besides the (pre-Maastricht EC and post-Maastricht) EU and NATO, there was the Council of Europe, the CSCE (after the 1993 Budapest summit, OSCE), the EBRD and EIB. All of them were sending the political, economic, human dimension, commercial signals, assistance and expertise. Through the EBRD-EIB conditionalities and EU accession criteria, Eastern Europe was dictated to practically dismantle its essential industrial and service base. This dictatum upon defeated belligerent - euphemistically called countries in transition or new Europe - was followed by loans and assets received from the EU Accession and Structural funds. It was "sold" to the East as award and as such presented to the deceived population. (However, it was rather to tranquilize the population at large and to pacify their local scenes, not at all aimed to modernize, re-industrialize or diversify economy, or to make production and service sector more efficient or competitive. Consequently, it was merely to subsidize the deteriorating purchasing power of the East - to make the peoples there accustomed to and encouraged for the foreign goods and services.) Thus, the funds were predominantly consumed for the western commodities. Ergo, Atlantic and Central Europe extended themselves geographically, while economically they skillfully managed to subsidize their own ind ustrial base. To this very end, Eastern Europe's elites readily took loans, while -in return- laying down sovereignty by issuing the state-debt guaranties. By doing so, they indebted their own states beyond bearing, and hence, they finally eliminated their own countries as any current or future economic competitor or politico-military challenger. These moves were making both sides very nervous; Russia becoming assertive (on its former peripheries) and Eastern Europe defiantly dismissive. Until this very day, each of them is portraying the NATO enterprise as the central security consideration: One as a must-go, and another as a no-go.

No wonder that the absolute pivot of Eastern Europe - Ukraine, is a grand hostage of that very dilemma: Between the eastern pan-Slavic hegemony and western "imperialism of free market" (This is further burdened by the imperialism in a hurry - an inflammable mix of the Lithuanian-Polish past traumas and German "manifest destiny" of being historically yet again ill-fated; impatient for quick results - simply, unable to capitalize on its previous successes. One of my German students recently very vividly satirized: "The irony of unintended consequence is that the intense relationship between Über-mutti (Chancellor Merkel) and boxman at large Klitschko is interpreted by Moscow as asexual, but not as apolitical." To say, overly cosmopolitan interest for a faith 
of foreigners living in Germany for someone who infamously said: "multiculturalism is dead in Europe..." (Sarkozy, Cameron and Merkel openly and repeatedly viewed and diagnosed "death of multiculturalism'), as if the cluster of Atlantic-Central Europe's national-states lived a long, cordial and credible history of multiculturalism on its soil.). For Ukraine, Russia is a geographic, sociohistoric, cultural and linguistic reality. These days, this reality is far less reflected upon than the seducing, but distant Euro-Atlantic club. Ukraine for Russia is more than a lame western-flank" geopolitical pivot, or to say, the first collateral in the infamous policy of containment that the West had continuously pursued against Russia ever since the $18^{\text {th }}$ century. For Moscow, Kiev is an emotional place - an indispensable bond of historiocivilizational attachment - something that makes and sustains Russia both Christian and European. Putin clearly redlined it: Sudden annexation of Crimea (return to its pre-1954 status) was an unpleasant and humiliating surprise that brings a lot of foreign policy hangover for both the NATO and EU.

Thus drifting chopped off and away, a failed state beyond rehabilitation, Ukraine itself is a prisoner of this domesticated se- curity drama. Yet again, the false dilemma so tragically imploded within this blue state, of a 50:50 polarized population, over the question where the country belongs - in space, time and side of history. Conclusively, Eastern Europe is further twisting, while gradually combusted between Ukrainization and Pakistanization (Ukrainization could be attributed to eastern and western Slavs- who are fighting distinctions without significant difference. Pakistanization itself should describe the southern Slavs' scenery: In lieu of truth and reconciliation, guilt is offered as a control mechanism, following the period of an unchecked escalation, ranging from a hysteria-of-a-small-difference to a crime-of-otherness purge). The rest of Europe is already shifting the costs of its own foreign policy journey by "fracking" its households with a considerably higher energy bills.

In short, Atlantic Europe is a political powerhouse, with two of three European nuclear powers and 2 out of five permanent members of the UN Security Council, P- ${ }^{[1]}$. Central Europe is an economic powerhouse, Russophone Europe is an energy powerhouse, Scandinavian Europe is all of that a bit, and Eastern Europe is none of it.

\section{References (transliterated)}

1. Bajrektarević, A. (2013), Future of Europe (Of Lisbon and Generational Interval), EU Journal Europe's World, Brussels

2. Brzezinski, Z. (1997), The Grand Chessboard, Basic Books (Perseus);

3. Fukuyama, F. (2012), The Future of History, Foreign Affairs Magazine 91(1) 2012

4. Friedman, G. (2009), The Next 100 Years, Anchor Books/Random House NY;

5. Ferguson, N. (2005), Colossus - The Rise and Fall of the American Empire, Penguin Books (page 255)

6. Bajrektarević, A. (2005), Green/Policy Paper Submitted to the closing plenary of the Ministerial (Chairmanship summarizing the recommendations and conclusions of the OSCE Ministerial Summit Prague 2005), OSCE Documents/EEA 2005/05/14857/En

7. Clark, C. (2013), The Sleepwalkers: How Europe Went to War in 1914, HarperCollins Publishers

8. Eco, U. (2001), Eternal Fascism: 14 way of looking at a Blackshirt, Five Moral Pieces Essays (orig. Cinque Scritti Morali, 1997), Essay first published in the NY Review of Books, 22 VI 1995 (pp.12-15) 
9. Stiglitz, J.E. (2012), The Price of Inequality, Penguin Economics

10. Wallerstein, I. (1999), The End of the World as We Know it: Social Science for the XXI century, Minneapolis: University of Minnesota Press

11. OECD (2014), Society at a Glance 2014 - The Crisis and its Aftermath (OECD Social Indicators), OECD Paris Publications

12. World Bank (2014), World Development Report 2014: Risk and Opportunity — Managing Risk for Development, WB Publications

13. Mead, W.R. (2014), The Return of Geopolitics — The Revenge of the Revisionist Powers, Foreign Affairs Magazine 93(2) 2014

14. Greco, T.H. (2009), The End of Money and the Future of Civilization, Chelsea Green Publishing

15. Serfaty, S. (2014) Why we need to be patient with Russia, Europe's World - the EU Foreign Policy Journal, Brussels (page 73)

16. Bajrektarević, A. (2013), Multiculturalism is D(r)ead in Europe - MENA Oil and the (hidden) political prize Europe pays for it, Nordic Page, Oslo Norway

17. Ikenberry, G.J. (2014), The Illusion of Geopolitics, Foreign Affairs Magazine 93(3) 2014

18. Kagan, R. (2004), Of Paradise and Power, Vintage Books (page 85) 